\title{
PERAN TEAMWORK DAN TIME PRESSURE TERHADAP KINERJA DENGAN AFFECTIVE COMMITMENT SEBAGAI VARIABEL INTERVENING
}

\author{
Candra Auromiqo ${ }^{1)}$, Indarto Indarto ${ }^{2)}$, Djoko Santoso3) \\ Candra@gmail.com ${ }^{1)}$; indarto@usm.ac.id ${ }^{2)}$ djoko_hw@usm.ac.id \\ Program Studi Magister Manajemen, Universitas Semarang, Semarang Indonesia
}

\begin{tabular}{l} 
Info Artikel \\
\hline Sejarah Artikel: \\
Diterima : Des. 2019 \\
Disetujui : Des.2019 \\
Dipublikasikan : \\
Desember 2019 \\
\hline Keywords: \\
affective commitment; \\
performance; teamwork; \\
time pressure.
\end{tabular}

\section{Info Artikel}

\begin{abstract}
Abstrak
Tujuan penelitian untuk mengetahui pengaruh teamwork dan time pressure terhadap affective commitment yang berdampak pada kinerja auditor BPK Perwakilan Provinsi Jawa Tengah. Variabel yang digunakan adalah teamwork dan time pressure sebagai variabel independen, kinerja sebagai variabel dependen serta affective commitment sebagai variabel intervening. Sampel yang digunakan adalah auditor BPK Perwakilan Provinsi Jawa Tengah yang berjumlah 100 responden, pengambilan sampel menggunakan purposive sampling. Metode pengumpulan data yang digunakan adalah kuesioner (angket). Pengolahan data menggunakan PLS. Analisis yang digunakan meliputi outer model, uji validitas, uji reliabilitas, inner model, dan uji hipotesis. Berdasarkan hasil analisis dapat diketahui bahwa teamwork dan time pressure berpengaruh terhadap affective commitment, time pressure berpengaruh terhadap kinerja tetapi teamwork tidak berpengaruh terhadap kinerja, dan affective commitment bukan sebagai variabel intervening hubungan antara variabel teamwork dan time pressure terhadap kinerja auditor BPK Perwakilan Provinsi Jawa Tengah.
\end{abstract}

THE ROLE OF TEAMWORK AND TIME PRESSURE ON PERFORMANCE WITH AFFECTIVE COMMITMENT AS AN INTERVENING VARIABLE

\begin{tabular}{|c|c|}
\hline & Abstract \\
\hline & $\begin{array}{l}\text { The aim of the study was to determine the effect of teamwork and time pressure on affective } \\
\text { commitment which had an impact on the performance of the auditors in BPK Representative } \\
\text { Office of Central Java. Variables used are teamwork and time pressure as independent variables, } \\
\text { performance as dependent variable and affective commitment as intervening variables. The sample } \\
\text { used was the auditor in BPK Representative Office of Central Java, amounting to } 100 \text { respondents, } \\
\text { sampling using purposive sampling. Data collection method used is questionnaire. The analysis } \\
\text { used includes outer model, validity test, reliability test, inner model, and hypothesis test. Based on } \\
\text { the results of the analysis it can be seen that teamwork and time pressure have an influence on } \\
\text { affective commitment, time pressure have an influence on performance but teamwork has no effect } \\
\text { on their performance, and affective commitment is not an intervening variable of the relationship } \\
\text { between teamwork and time pressure variable on the performance of the BPK Representative Office } \\
\text { of Central Java Auditors. }\end{array}$ \\
\hline Alamat korespondensi : & 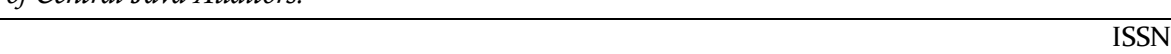 \\
\hline Jl Soekarno-Hatta Semaran & 1979-48oo (cetak) \\
\hline E-mail: indarto@usm.ac.id & $2580-8451$ (online) \\
\hline
\end{tabular}




\section{PENDAHULUAN}

Keberadaan sumber daya manusia sangat penting dalam mendukung operasional dan aktivitas organisasi sesuai dengan tuntutan dinamika perkembangan jaman. Oleh karenanya sangat beralasan kalau banyak instansi berorientasi mengembangkan kemampuan sumber daya manusianya secara optimal, karena akan berdampak pada kinerja karyawannya.

Kinerja pegawai dapat dilihat dari seberapa jauh komitmen pegawai tersebut terhadap instansinya. Affective commitment merupakan salah satu bentuk komitmen organisasi yang harus dimiliki oleh seorang pegawai. Oleh karena itu pegawai yang memiliki komitmen afektif terhadap organisasi menjadi sangat penting, karena dengan komitmen afektif yang tinggi akan meningkatkan kinerja pegawai berdasarkan rasa cintanya terhadap instansi dan akan mempengaruhi perkembangan instansi.

Penelitian ini mengambil obyek di Badan Pemeriksa Keuangan (BPK) Perwakilan Provinsi Jawa Tengah, dimana BPK sebagai lembaga negara yang bebas dan mandiri dalam memeriksa pengelolaan dan tanggung jawab keuangan negara, senantiasa berupaya agar pegawai yang bekerja pada instansinya, khususnya auditor memiliki kinerja yang tinggi.

Berdasarkan pengamatan awal terdapat fenomena permasalahan pada BPK Perwakilan Provinsi Jawa Tengah yaitu adanya penurunan kinerja yang terlihat dari realisasi Indikator Kinerja Utama (IKU) BPK Perwakilan Provinsi Jawa Tengah yang belum mencapai target yang telah ditetapkan dan terdapat kenaikan absensi auditor tanpa adanya keterangan yang mengindikasikan penurunan affective commitment para auditor.

Beberapa penelitian tentang pengaruh komitmen afektif terhadap kinerja telah dilakukan. Penelitian Suswati dan Budianto (2013), Nurbiyati dan Wibisono (2014) menunjukkan hasil bahwa komitmen afektif berpengaruh positif terhadap kinerja karyawan. Penelitian Nurandini dan Lataruva (2014), Tree dan Suryoko (2016) dan Pathan, Natsir dan Adda (2017), hasilnya komitmen afektif berpengaruh positif dan signifikan terhadap kinerja karyawan. Sedangkan hasil penelitian yang dilakukan oleh Yeh Hong (2012), Arizona, Iriwati dan Harahap (2013) dan Subejo, Troena, Thoyib dan Aisjah (2013) menunjukkan hasil bahwa komitmen afektif tidak memiliki pengaruh yang signifikan terhadap kinerja karyawan.

Fenomena permasalahaan tersebut diduga juga dilatarbelakangi oleh rendahnya teamwork (kerjasama tim), dan adanya time pessure (tekanan waktu). Teamwork merupakan faktor terpenting dalam kelancaran sebuah organisasi. Keberhasilan teamwork diraih ketika mereka dapat melenyapkan kompetisi dan selalu konsentrasi pada perbedaan pandangan dan kemampuan serta keahlian dengan tujuan mengatasi masalah dan tantangan yang muncul secara cepat (Manzooe et.al, 2011).

Selain kurangnya kerjasama tim, time pressure yang dirasakan oleh auditor di BPK Perwakilan Provinsi Jawa juga berpengaruh terhadap kinerja auditor. Auditor yang mengalami time pressure dapat merespon dalam dua cara, yaitu dengan bekerja lebih keras atau semakin efisien dalam menggunakan waktu. Meskipun time pressure dipandang dapat menurunkan kinerja, namun apabila alokasi waktu dilakukan dengan tepat justru berfungsi sebagai mekanisme kontrol bagi kinerja auditor (Rustiarini, 2013).

Berdasarkan beberapa penelitian yang terkait dengan pengaruh teamwork dan time pressure terhadap kinerja terdapat research gap sebagaimana pada tabel berikut. 
Tabel 1

Research Gap

\begin{tabular}{|c|c|}
\hline Research Gap & Peneliti \\
\hline $\begin{array}{l}\text { Issue : Terdapat kontradiksi tentang pengaruh } \\
\text { teamwork terhadap kinerja } \\
\text { a Teamwork berpengaruh signifikan terhadap } \\
\text { kinerja }\end{array}$ & $\begin{array}{c}\text { Mohammad Qasim and Shahid } \\
\text { Rasheed (2017) }\end{array}$ \\
\hline b Teamwork tidak berpengaruh terhadap kinerja & $\begin{array}{c}\text { Dian Rakhmawati dan Susetyo } \\
\text { Darmanto (2014) }\end{array}$ \\
\hline $\begin{array}{l}\text { Issue : Terdapat kontradiksi tentang pengaruh } \\
\text { time pressure terhadap kinerja } \\
\text { c Time pressure berpengaruh signifikan } \\
\text { terhadap kinerja } \\
\text { d Time pressure tidak berpengaruh terhadap } \\
\text { kinerja }\end{array}$ & Moore dan Tenney (2012) \\
\hline
\end{tabular}

Sumber : Disarikan dari berbagai jurnal terdahulu, 2019

Dengan demikian rumusan masalah dalam penelitian ini adalah bagaimana upaya manajemen meningkatkan kinerja auditor dengan mengatasi research gap yang ada.

Dari hasil penelitian ini diharapkan dapat mencapai beberapa tujuan yaitu untuk menganalisis dan membuktikan secara empiris pengaruh teamwork terhadap affective commitment; pengaruh time pressure terhadap affective commitment; pengaruh teamwork terhadap kinerja; pengaruh affective commitment terhadap kinerja; dan pengaruh time pressure terhadap kinerja.

\section{TELAAH PUSTAKA}

\section{Kinerja}

Robbins (2003) menyebutkan bahwa kinerja pegawai itu dipengaruhi oleh kemampuan, motivasi dan kesempatan, baik kemampuan atas dasar kecerdasan atau ketrampilan, namun tidak membahas faktor-faktor lain yang mempengaruhi kinerja. Sedangkan faktor-faktor yang mempengaruhi kinerja menurut Kasmir (2016), antara lain: a. Budaya Organisasi, Kepuasan Kerja, Lingkungan Kerja, Loyalitas, Komitmen.

Menurut Bernadin dalam Priyono, 2016 disebutkan bahwa indikator kinerja antara lain mampu menyelesaikan pekerjaan tepat waktu sesuai dengan yang ditentukan oleh instansi (Quantity of work), kualitas pekerjaan yang dihasilkan sesuai dengan harapan (Quality of work), memiliki pengetahuan yang mendalam tentang pekerjaan yang dihadapi (Job Knowledge), memiliki banyak ide terkait dengan penyelesaian pekerjaan (Creativeness), dan mampu bekerja sama dengan rekan sekerja (Cooperation).

Berdasarkan hal tersebut, terdapat beberapa faktor yang dapat mempengaruhi kinerja seorang pegawai antara lain kemampuan dalam bekerjasama (teamwork), kemampuan menyelesaikan pekerjaan tepat waktu sebagai bentuk pengelolaan time pressure dan komitmen kerja pegawai dimana didalamnya terdapat affective commitment sebagai bentuk ikatan emosional dan tanggungjawab pegawai terhadap instansi.

Dalam profesi auditor, kinerja merupakan hasil kerja yang dicapai oleh auditor dalam melaksanakan tugasnya, sesuai dengan tanggung jawab yang diberikan padanya dan menjadi salah satu tolak ukur yang digunakan untuk menentukan pekerjaan yang dilakukan akan baik atau sebaliknya. 


\section{Affective Commitment}

Affective commitment merupakan salah satu komitmen organisasi yang harus dimiliki oleh seorang pegawai. Affective commitment ini merupakan ikatan secara emosional yang melekat pada seorang pegawai untuk mengidentifikasikan dan melibatkan dirinya dengan organisasi (Meyer, Allen \& Smith, 2003 dalam Kurnia, 2016). Oleh karena itu pegawai yang memiliki komitmen afektif terhadap organisasi menjadi sangat penting, karena dengan komitmen afektif yang tinggi akan meningkatkan kinerja pegawai berdasarkan rasa cintanya terhadap instansi dan akan mempengaruhi perkembangan instansi (Kusumastuti dan Nurtjahjanti, 2013).

Faktor yang mempengaruhi/mendukung komitmen afektif antara lain adalah karakteristik personal, dan karakteristik struktural. Faktor karakteristik personal/pribadi terdiri dari variabel demografis yang mencakup gender, usia, status pernikahan, tingkat pendidikan dan lamanya seseorang bekerja pada suatu organisasi, dan variabel disposisional yang mencakup kepribadian dan nilai yang dimiliki anggota organisasi.

Karakteristik struktural/organisasi yaitu struktur organisasi, desain kebijaksanaan dalam organisasi dan bagaimana kebijaksanaan organisasi tersebut disosialisasikan diantaranya termasuk pada kebijakan yang berorientasi pada waktu pelaksanaan pekerjaan.

Berdasarkan definisi tersebut di atas, maka terdapat beberapa faktor pendukung affective commitment antara lain kemampuan pegawai dalam bekerjasama (teamwork) sebagai salah satu faktor karakteristik personal dan orientasi pada waktu pelaksanaan pekerjaan sebagai faktor karakteristik struktural dalam pengelolaan time pressure.

Dalam hal ini profesi sebagai auditor sangat memerlukan affective commitment yang baik supaya dapat meningkatkan kinerja melalui pengelolaan teamwork yang baik dan meminimalisir dampak negatif atas time pressure.

\section{Teamwork}

Teamwork adalah proses bekerja dalam sebuah kelompok yang dipimpin oleh seorang pemimpin yang memiliki gaya kepemimpinan partisipatif, berbagi tanggung jawab, lurus dalam tujuan, komunikasi yang intensif, fokus ke masa depan, fokus pada tugas, bakat yang kreatif dan responsif untuk mencapai tujuan organisasi (Safitri, 2012).

Upaya untuk mencapai produktivitas kerja yang tinggi dengan hasil yang lebih, setiap orang harus bekerja melalui sebuah kelompok yang bekerja secara kooperatif sehingga teamwork merupakan faktor terpenting dalam kelancaran sebuah organisasi. Dalam hal ini profesi sebagai auditor sangat memerlukan pengelolaan teamwork yang baik supaya dapat meningkatkan kinerja.

\section{Time Pressure}

Time pressure (tekanan waktu) adalah kendala yang timbul, karena adanya keterbatasan waktu atau keterbatasan sumberdaya yang dialokasikan untuk melaksanakan penugasan (DeZoort \& Lord, 2007 dalam Rustiarini, 2013). Time pressure adalah suatu kondisi dimana pegawai mendapatkan tekanan dari tempatnya bekerja untuk dapat menyelesaikan pekerjaannya sesuai dengan waktu yang telah ditetapkan (Maulina, dkk, 2010).

Gundry (2016) berpendapat bahwa penurunan kualitas kerja auditor hanya terjadi apabila auditor mengalami tekanan waktu yang tinggi, namun penurunan kualitas kerja tidak akan terjadi apabila auditor mengalami tekanan waktu yang rendah. 
Auditor yang mengalami time pressure dapat merespon dalam dua cara, yaitu dengan bekerja lebih keras atau semakin efisien dalam menggunakan waktu. Apabila diperlukan, maka auditor dapat meminta tambahan waktu pada atasannya (Otley dan Pierce, 2016) dan menggunakan prosedur audit yang lebih efisien (Coram et al., 2013). Meskipun time pressure dipandang dapat menurunkan kinerja, nmun apabila alokasi waktu dilakukan dengan tepat justru berfungsi sebagai mekanisme kontrol bagi kinerja auditor (Rustiarini, 2013).

Dalam hal ini profesi sebagai auditor sangat membutuhkan pengelolaan time pressure yang tepat dalam melaksanakan pekerjaan agar tidak mengganggu pencapaian kinerja yang baik. Berdasarkan latar belakang permasalahan dan telaah pustaka tersebut maka perumusan hipotesis penelitian dapat diuraikan sebagai berikut;(1) $\mathrm{H}_{1}$ : Teamwork berpengaruh terhadap affective commitment;(2) $\mathrm{H}_{2}$ : Time pressure berpengaruh terhadap affective commitment;(3) $\mathrm{H}_{3}$ : Teamwork berpengaruh terhadap kinerja; (4) $\mathrm{H}_{4}$ : Affective commitment berpengaruh terhadap kinerja; (5) $\mathrm{H}_{5}$ : Time pressure berpengaruh terhadap kinerja.

\section{Kerangka Pemikiran Teoritis}

Berdasarkan latar belakang permasalahan yang dihadapi oleh Auditor BPK Perwakilan Provinsi Jawa Tengah dan telaah pustaka yang ada, maka kerangka pemikiran teoritis dalam penelitian ini dapat digambarkan sebagai berikut.

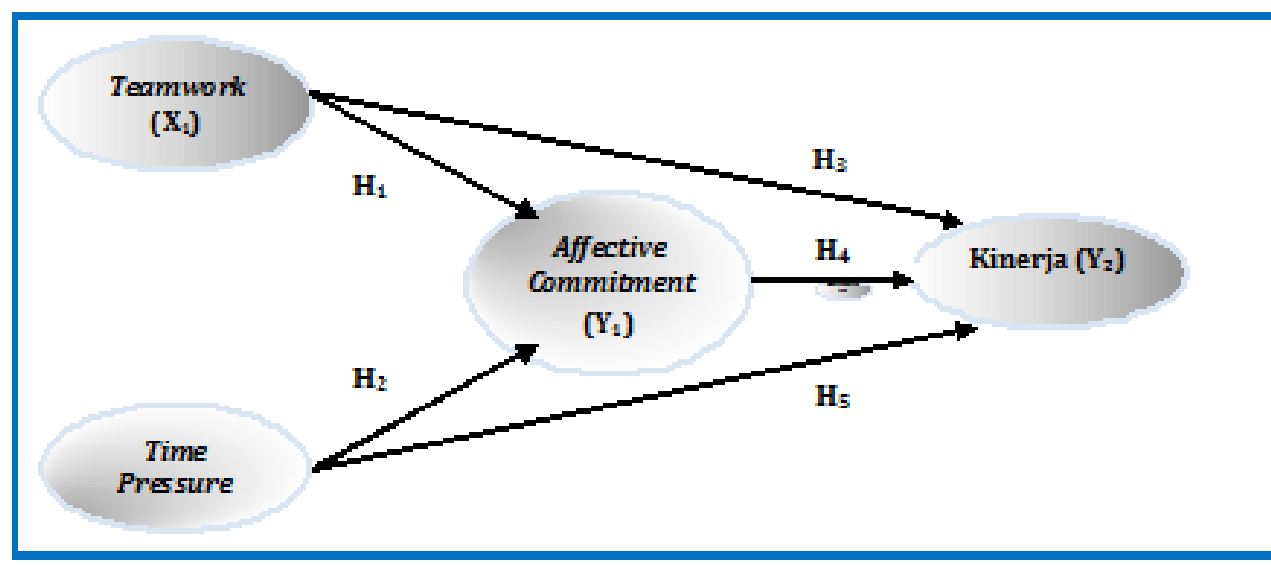

Gambar 1

Kerangka Pemikiran Teoritis

\section{METODE}

\section{Jenis Penelitian, Jenis Data dan Sumber Data}

Jenis penelitian yang digunakan adalah explanatory dengan pendekatan kuantitatif. Penelitian explanatory yaitu jenis penelitian yang bermaksud menjelaskan hubungan kausal antara variabel-variabel yang mempengaruhi hipotesis dan secara umum data yang disajikan adalah dalam bentuk angka-angka yang dihitung melalui uji statistik (Sugiyono, 2012). 
Jenis data yang digunakan adalah data subyek, yaitu jenis data penelitian yang berupa opini, sikap, pengalaman atau karakteristik dari seseorang atau sekelompok orang yang menjadi subyek penelitian (Ferdinand, 2006 dalam Prasetyo, 2016). Sumber data yang digunakan adalah data primer yang dikumpulkan melalui penyebaran kuesioner yang telah dibuat dan disusun dalam bentuk rangkaian pernyataan-pernyataan sesuai dengan data variabel yang akan diteliti, yaitu teamwork, time pressure, affective commitment dan kinerja pegawai.

\section{Populasi dan Penentuan Sampel}

Populasi dalam penelitian ini adalah seluruh pegawai BPK Perwakilan Provinsi Jawa Tengah yang bertugas sebagai auditor sebanyak 138 orang. Teknik pengambilan sampel yang digunakan dalam penelitian ini adalah non probability sampling dengan pendekatan purposive sampling yaitu peneliti memilih sampel purposive secara subyektif (Ferdinand, 2006 dalam Prasetyo, 2016). Sampling purposive adalah teknik penentuan sampel dengan pertimbangan tertentu.

Dalam penelitian multivariate penentuan jumlah minimal sampel dihitung berdasarkan rumus sebagai berikut (Ferdinand, 2006 dalam Prasetyo, 2016):

$\mathrm{n} \quad=5 \times \Sigma$ Indikator

Dimana :

$\mathrm{n}=$ Jumlah sampel

$\Sigma=$ Jumlah total indikator penelitian

Hasil perhitungan: $\mathrm{n}=5 \times 20$ $\mathrm{n}=100$

Berdasarkan hasil perhitungan yang telah dilakukan, maka jumlah sampel dalam penelitian ini sebanyak 100 orang.

\section{Variabel Penelitian}

Variabel pada penelitian ini dikelompokan menjadi 3 (tiga) yaitu variabel independen, variabel intervening, dan variabel dependen. Variabel independen yaitu teamwork $\left(\mathrm{X}_{1}\right)$ dan time pressure $\left(\mathrm{X}_{2}\right)$. Variabel intervening yaitu affective commitmet $\left(\mathrm{Y}_{1}\right)$, dan variabel dependen yaitu kinerja $(\mathrm{Y} 2)$.

\section{Metode Pengumpulan Data}

Metode pengumpulan data dengan cara menyebarkan kuesioner ke responden berupa daftar pertanyaan yang berhubungan dengan data dan informasi tentang teamwork, time pressure, affective commitment dan kinerja. Dalam penelitian ini jawaban yang diberikan oleh responden kemudian diberi skor dengan mengacu pada skala Likert.

\section{Teknik Analisis Data}

Teknik analisis data menggunakan metode analisis deskriptif dan kuantitatif. Analisis deskriptif dilakukan dengan menggunakan teknik analisis indeks, untuk menggambarkan persepsi responden atas item-item pertanyaan yang diajukan mengenai variabel-variabel penelitian yang digunakan dengan teknik skoring dengan skor maksimal 7 dan minimal 1.

Analisis kuantitatif diharapkan akan didapatkan hasil pengukuran yang lebih akurat tentang respon yang diberikan oleh responden, sehingga data yang berbentuk 
angka tersebut dapat diolah dengan menggunakan metode statistik. Analisis data dilakukan dengan menggunakan metode Partial Least Square (PLS). Dengan menggunakan PLS dapat dilakukan analisis model struktural (inner model) yang menunjukkan kekuatan estimasi antar variabel laten/konstruk dan analisis evaluasi model pengukuran (outer model) yang menunjukkan bagaimana variabel manifest merepresentasi variabel laten untuk diukur.

\section{HASIL DAN PEMBAHASAN}

\section{Profil Responden Penelitian}

Jumlah auditor laki-laki pada BPK Perwakilan Provinsi Jawa Tengah lebih banyak daripada jumlah auditor perempuan. Hal ini dikarenakan intensitas pekerjaan di lapangan dan tuntutan target yang tinggi dengan jam kerja yang padat, sehingga komposisi jenis kelamin laki-laki lebih banyak.

Mayoritas responden penelitian berusia antara 33 sampai dengan 36,4 tahun, yaitu sebanyak 35 orang (35\%) sehingga dapat disimpulkan bahwa sebagian besar auditor di BPK Perwakilan Provinsi Jawa Tengah termasuk dalam kategori usia produktif, dan diharapkan dapat meningkatkan prestasi kerja auditor lebih baik lagi di masa yang akan datang.

Tingkat pendidikan mayoritas adalah Sarjana (S1) sebanyak 78 orang (78\%). Hal tersebut menunjukkan bahwa tingkat pendidikan auditor pada BPK Perwakilan Provinsi Jawa Tengah telah memadai. Tingkat pendidikan tersebut dapat mempengaruhi kemampuan pegawai dalam menyelesaikan pekerjaan maupun permasalahan yang dapat berdampak pada kinerja pegawai.

Mayoritas responden penelitian telah memiliki masa kerja antara 9,5 sampai dengan 11,9 tahun, sebanyak 35 orang (35\%) dan antara 12 sampai dengan 14,4 tahun, sebanyak 34 orang (34\%). Hal tersebut dapat disimpulkan bahwa auditor di BPK Perwakilan Provinsi Jawa Tengah memiliki masa kerja yang cukup dan akan berpengaruh terhadap pengalaman kerja yang dimiliki.

Status pernikahan responden terbesar adalah menikah sebanyak 87 orang (87\%). Hal ini menandakan bahwa mayoritas pegawai BPK Perwakilan Provinsi Jawa Tengah telah berkeluarga atau memiliki tanggungan keluarga. Dengan pola kerja yang ada di BPK Perwakilan Provinsi Jawa Tengah, menuntut auditor yang menikah tetap memiliki komitmen afektif yang tinggi agar dapat menjaga maupun meningkatkan kinerja.

\section{Analisis Data}

Analisis Deskriptif

\section{Tanggapan tentang Teamwork (X1)}

Tanggapan responden tentang teamwork merupakan penilaian dari responden penelitian tentang indikator-indikator dari teamwork yang terjadi di lingkungan auditor di BPK Perwakilan Provinsi Jawa Tengah. Skor rata-rata tanggapan responden tentang teamwork diperoleh nilai sebesar 81,00 yang artinya skor berada pada interpretasi indeks yang tinggi. Hal ini menunjukkan bahwa persepsi atas teamwork yang terjalin pada pegawai BPK Perwakilan Provinsi Jawa Tengah termasuk dalam kategori tinggi.

\section{Tanggapan tentang Time Pressure $\left(\mathrm{X}_{2}\right)$}

Tanggapan dari responden penelitian tentang time pressure auditor BPK Perwakilan Provinsi Jawa Tengah merupakan penilaian dari responden tentang indikator-indikator time pressure. Skor rata-rata tanggapan responden tentang time 
pressure diperoleh nilai sebesar 79,14 yang artinya skor berada pada interpretasi indeks yang tinggi. Hal ini menunjukkan bahwa persepsi auditor BPK Perwakilan Provinsi Jawa Tengah atas time pressure termasuk dalam kategori tinggi.

\section{Tanggapan tentang Affective Commitment $\left(\mathbf{Y}_{1}\right)$}

Tanggapan dari responden penelitian tentang affective commitment yang dirasakan oleh auditor BPK Perwakilan Provinsi Jawa Tengah merupakan penilaian dari responden tentang indikator-indikator affective commitment. Skor rata-rata tanggapan responden tentang affective commitment diperoleh nilai sebesar 83,94 yang artinya skor berada pada interpretasi indeks yang tinggi. Hal ini menunjukkan bahwa persepsi auditor BPK Perwakilan Provinsi Jawa Tengah atas affective commitment termasuk dalam kategori tinggi.

\section{Tanggapan tentang Kinerja $\left(\mathrm{Y}_{2}\right)$}

Tanggapan dari responden penelitian tentang kinerja yang telah dicapai oleh auditor BPK Perwakilan Provinsi Jawa Tengah merupakan penilaian dari responden tentang indikator-indikator kinerja. Skor rata-rata tanggapan responden tentang kinerja diperoleh nilai sebesar 84,94 yang artinya skor berada pada interpretasi indeks yang tinggi. Hal ini menunjukkan bahwa persepsi auditor BPK Perwakilan Provinsi Jawa Tengah atas kinerja termasuk dalam kategori tinggi.

\section{Model dan Teknik Analisis Data}

\section{Outer Model}

Evaluasi Model Pengukuran (outer model) digunakan untuk mengevaluasi hubungan antara konstrak dengan indikatornya dibagi menjadi dua (2) yaitu convergent validity dan discriminant validity. Hasil pengukuran outer model adalah sebagai berikut:

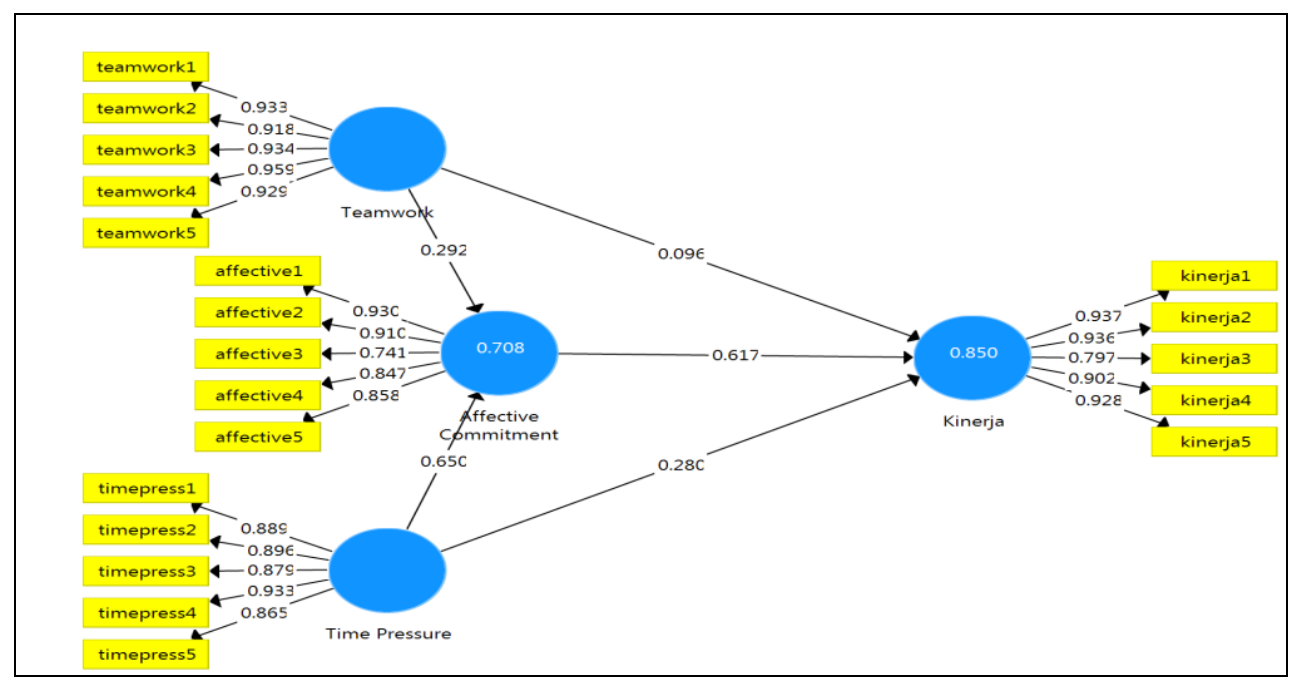

Gambar 2

Outer Model berikut:

Pengukuran convergent validity dan discriminant validity dapat dijelaskan sebagai

\section{Convergent Validity}


Convergent Validity (uji validitas) adalah suatu alat yang digunakan untuk mengukur sah/valid tidaknya suatu kuesioner. Convergent Validity dari model pengukuran dapat dilihat dari korelasi antara skor indikator dengan skor variabelnya (loading factor) dengan kriteria nilai loading factor dari setiap indikator lebih besar dari 0,70 dapat dikatakan valid. Hasil pengujian validitas menunjukkan bahwa seluruh indikator memiliki loading factor diatas 0,7 atau memiliki keterkaitan yang baik dengan konstruknya. Sehingga seluruh indikator tersebut dinyatakan valid.

\section{Discriminant Validity}

Discriminant validity dari model pengukuran dengan reflektif indikator dinilai berdasarkan cross loading pengukuran dengan konstruk. Hasil pengujian discriminant validity menunjukkan bahwa seluruh indikator pada variabel penelitian memiliki nilai cross loading terbesar pada variabel yang dibentuknya dibandingkan dengan nilai cross loading pada variabel lainnya. Berdasarkan hasil yang diperoleh tersebut, dapat dinyatakan bahwa indikator-indikator yang digunakan dalam penelitian ini telah memiliki discriminant validity yang baik dalam menyusun variabelnya masing-masing. Selain mengamati nilai cross loading, discriminant validity juga dapat diketahui melalui metode lainnya yaitu dengan melihat nilai Average Variant Extracted (AVE) untuk masing-masing indikator dipersyaratkan nilainya harus $>0,5$ untuk model yang baik (Ghozali, 2014). Hasilnya menunjukkan bahwa nilai AVE seluruh variabel lebih tinggi dari 0,5. Dengan demikian dapat dinyatakan bahwa setiap variabel telah memiliki discriminant validity yang baik.

\section{Uji Realibilitas}

Uji realibilitas variabel dapat diukur dengan dua kriteria yaitu composite reliability dan cronbach's alpha. Suatu variabel dinyatakan reliabel jika nilai composite reliability $>0,70$. Composite reliability dari masing-masing variabel yaitu teamwork 0.972, time pressure 0.951, affective commitment 0.934 dan kinerja 0.956. Adapun untuk hasil dari cronbach's alpha untuk teamwork 0,964, time pressure 0,936, affective commitment 0,910 dan kinerja 0,942. Berdasarkan hasil dari composite reliability dan cronbach's alpha, dapat disimpulkan bahwa keseluruhan variabel telah memiliki tingkat reliabilitas yang tinggi atau handal.

\section{Inner Model}

Analisis inner model dilakukan untuk memastikan bahwa model struktural yang dibangun kokoh dan akurat. Evaluasi struktural (inner model) meliputi uji path coefficient, uji kebaikan model (goodness of fit) dan uji hipotesis. 
Hasil pengukuran inner model adalah sebagai berikut:

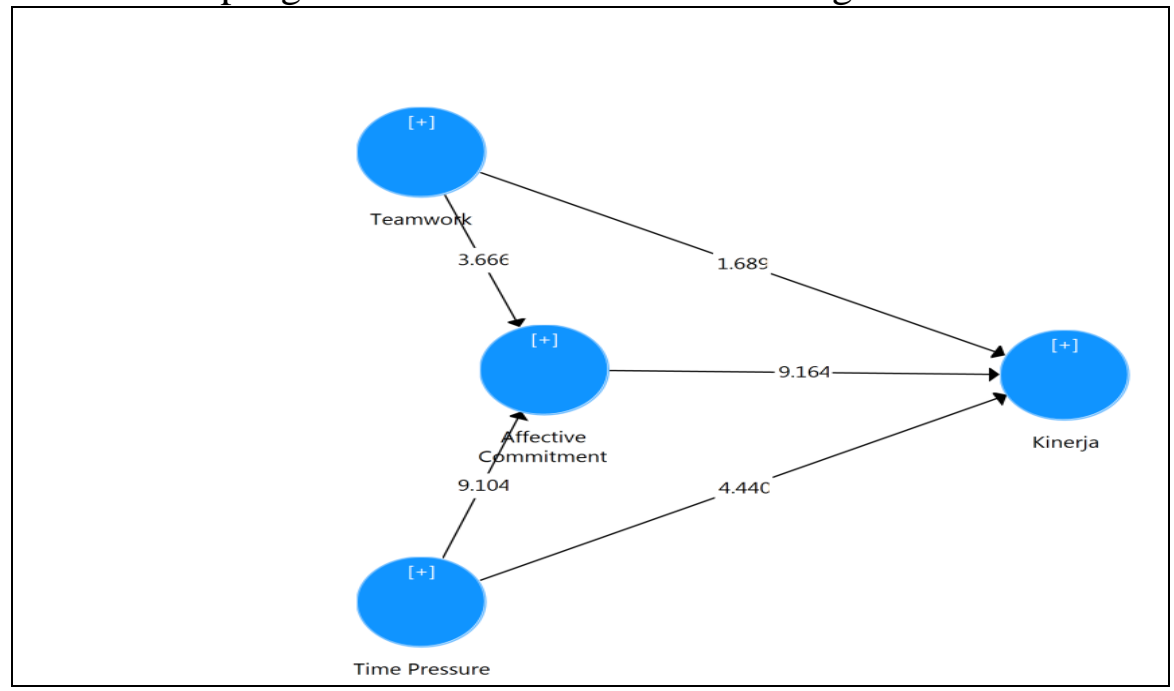

Gambar 3

Inner Model

\section{Uji Path Coefficient}

Uji path coefficient digunakan untuk menunjukkan seberapa kuat efek atau pengaruh variabel independen terhadap variabel dependen. Berdasarkan skema inner model yang ditampilkan pada gambar diatas dapat dijelaskan bahwa nilai path coefficient sebagai berikut.

\section{Tabel 2}

Nilai Path Coefficient

\begin{tabular}{|c|r|r|r|r|r|}
\hline Pengaruh Model & $\begin{array}{c}\text { Original } \\
\text { Sample } \\
\text { (0) }\end{array}$ & $\begin{array}{c}\text { Sample } \\
\text { Mean (M) }\end{array}$ & $\begin{array}{c}\text { Standard } \\
\text { Deviation } \\
\text { (STDEV) }\end{array}$ & $\begin{array}{c}\text { T Statistics } \\
\text { (|O/STDEV|) }\end{array}$ & $\begin{array}{c}\text { P } \\
\text { Value }\end{array}$ \\
\hline Teamwork -> Affective Coomitment & 0.292 & 0.284 & 0.080 & 3.666 & 0.000 \\
\hline Time Pressure -> Affective Coomitment & 0.650 & 0.646 & 0.071 & 9.104 & 0.000 \\
\hline Teamwork ->Kinerja & 0.276 & 0.095 & 0.057 & 1.689 & 0.092 \\
\hline Affective Coomitment ->Kinerja & 0.617 & 0.613 & 0.067 & 9.164 & 0.000 \\
\hline Time Pressure ->Kinerja & 0.280 & 0.283 & 0.063 & 4.440 & 0.000 \\
\hline
\end{tabular}

Sumber: data diolah

Keseluruhan variabel dalam model ini memiliki path coefficient dengan angka yang positif. Hal ini menunjukkan bahwa jika semakin besar nilai path coefficient pada satu variabel independen terhadap variabel dependen, maka semakin kuat pula pengaruh antara variabel independen terhadap variabel dependen tersebut. Pengaruh terbesar adalah pengaruh affective commitment terhadap kinerja sebesar 9,164.

\section{Uji Kebaikan Model (Goodness of Fit)}

Uji kebaikan model dilakukan dengan melihat coefficient determination (R-Square). R-Square digunakan untuk mengukur seberapa banyak variabel endogen dipengaruhi oleh variabel lainnya. Hasil R-Square sebesar 0,67 ke atas 
mengindikasikan pengaruh variabel eksogen (yang mempengaruhi) terhadap variabel endogen (yang dipengaruhi) termasuk dalam kategori baik.

Hasil pengukuran menunjukkan bahwa R-Square untuk variabel affective commitment adalah 0,708 yaitu bahwa presentase besarnya affective commitment dapat dijelaskan oleh teamwork dan time pressure sebesar 70,8\%. Sedangkan $29,2 \%$ dijelaskan oleh variabel lain yang tidak terdapat dalam penelitian ini. Kemudian untuk nilai R-Square yang diperoleh variabel kinerja sebesar 0,850. Nilai tersebut menjelaskan bahwa kinerja dapat dijelaskan oleh teamwork, time pressure dan affective commitment sebesar $85 \%$. Adapun sebesar $15 \%$ dijelaskan oleh variabel lain yang tidak terdapat dalam penelitian ini.

Penilaian goodness of fit juga dapat diketahui dari nilai Q-Square. Adapun hasil perhitungan nilai Q-Square adalah sebagai berikut:

$$
\begin{aligned}
\text { Q-Square } & =1-[(1-\mathrm{R} 21) \times(1-\mathrm{R} 22)] \\
& =1-[(1-0,708) \times(1-0,850)] \\
& =1-(0,292 \times 0,150) \\
& =1-0,044 \\
& =0,956
\end{aligned}
$$

Berdasarkan hasil perhitungan tersebut, diperoleh nilai Q-Square sebesar 0,956 . Hal ini menunjukkan besarnya keragaman dari data penelitian yang dapat dijelaskan oleh model penelitian adalah sebesar 95,6\%. Sedangkan sisanya sebesar 4,4\% dijelaskan oleh faktor lain yang berada di luar model penelitian ini. Dengan demikian, dari hasil tersebut maka model penelitian ini dapat dinyatakan telah memiliki goodness of fit yang baik.

\section{Uji Hipotesis}

Pengujian hipotesis dimaksudkan untuk membuktikan kebenaran dugaan penelitian atau hipotesis. Uji hipotesis pada penelitian ini dilakukan dengan melihat nilai T-Statistics dan nilai P-Values. Hipotesis penelitian dapat dinyatakan diterima apabila nilai P-Values < 0,05 (Yamin dan Heri, 2011).

Hasil uji hipotesis yang diperoleh dalam penelitian ini melalui inner model adalah sebagai berikut:

\section{Tabel 3}

Nilai T-Statistics dan P-Values

\begin{tabular}{|c|c|c|c|}
\hline Pengaruh Variabel & T-Statistics & P-Values & Hasil \\
\hline Teamwork => Affective Commitment & 3,666 & 0,000 & $\mathrm{H}_{1}$ diterima \\
\hline Time Pressure => Affective Commitment & 9,104 & 0,000 & $\mathrm{H}_{2}$ diterima \\
\hline Teamwork => Kinerja & 1,689 & 0,092 & $\mathrm{H}_{3}$ ditolak \\
\hline Affective Commitment => Kinerja & 9,164 & 0,000 & $\mathrm{H}_{4}$ diterima \\
\hline Time Pressure => Kinerja & 4,440 & 0,000 & $\mathrm{H}_{5}$ diterima \\
\hline
\end{tabular}

Tabel diatas menunjukkan bahwa dari lima hipotesis yang diajukan dalam penelitian ini, empat hipotesis diterima yaitu $\mathrm{H} 1, \mathrm{H} 2, \mathrm{H} 4$, dan $\mathrm{H} 5$ karena masing-masing pengaruh yang ditunjukkan memiliki nilai P-Values $<0,05$. Sehingga dapat dinyatakan variabel independen ke dependennya memiliki pengaruh yang signifikan. Sedang untuk hipotesis H3 ditolak karena memiliki nilai P-Values $>0,05$. 


\section{Pembahasan}

\section{Pengaruh Teamwork terhadap Affective Commitment}

Hasil pengujian hipotesis menunjukkan bahwa teamwork dalam pelaksanaan tugas di BPK Perwakilan Provinsi Jawa Tengah berpengaruh terhadap affective commitment. Hasil penelitian ini sejalan dengan penelitian yang dilakukan Greenberg, et al. (2010) dan Purba (2015), yang menyimpulkan bahwa teamwork berpengaruh terhadap affective commitment. Hal tersebut dapat diartikan bahwa membangun/meningkatkan rasa memiliki terhadap BPK Perwakilan Provinsi Jawa Tengah dapat dilakukan dengan saling memberikan motivasi baik didalam tim maupun di lingkungan BPK Perwakilan Provinsi Jawa Tengah.

\section{Pengaruh Time Pressure terhadap Affective Commitment}

Hasil pengujian hipotesis menunjukkan bahwa time pressure dalam pelaksanaan tugas di BPK Perwakilan Provinsi Jawa Tengah berpengaruh terhadap affective commitment. Hasil penelitian tersebut sesuai dengan penelitian Suprapta (2016), Iswari (2015), Maya (2011) yang menyimpulkan bahwa time pressure berpengaruh terhadap affective commitment.

Hal tersebut dapat diartikan bahwa komitmen afektif para auditor dipengaruhi oleh pengelolaan time pressure yang tepat. Time pressure atas pelaksanaan tugas di BPK Perwakilan Provinsi Jawa Tengah juga dapat diatasi dengan bekerja secara efektif dan efisien maupun manajemen waktu yang baik. Dengan pengelolaan time pressure yang tepat maka hal tersebut dapat meningkatkan rasa memiliki terhadap BPK Perwakilan Provinsi Jawa Tengah.

\section{Pengaruh Teamwork terhadap Kinerja}

Hasil pengujian hipotesis menunjukkan bahwa teamwork tidak berpengaruh terhadap kinerja. Hasil penelitian tersebut tidak sesuai dengan hipotesis yang telah dinyatakan sebelumnya, namun sesuai dengan penelitian yang dilakukan oleh Rakhmawati dan Darmanto (2014) yang berkesimpulan bahwa teamwork tidak mempengaruhi kinerja.

Hal ini disebabkan karena keberhasilan teamwork diraih ketika mereka secara internal tim dapat melenyapkan kompetisi dan selalu konsentrasi pada perbedaan pandangan dan kemampuan serta keahlian untuk mencapai tujuan bersama. Teamwork di lingkungan BPK Perwakilan Provinsi Jawa Tengah juga dapat terjalin dengan baik melalui sikap toleransi, komunikasi yang baik dan adanya kegiatan-kegiatan kebersamaan (gathering).

\section{Pengaruh Affective Commitment terhadap Kinerja}

Hasil pengujian hipotesis menunjukkan bahwa affective commitment sebagai pegawai BPK Perwakilan Provinsi Jawa Tengah berpengaruh terhadap kinerja. Hasil penelitian tersebut sesuai dengan penelitian yang dilakukan oleh Suswati dan Budianto (2013), Nurbiyati dan Wibisono (2014), Nurandini dan Lataruva (2014), Tree dan Suryoko (2016) dan Pathan, Natsir dan Adda (2017) yang menyimpulkan bahwa affective commitment berpengaruh terhadap kinerja.

Hal tersebut dapat diartikan bahwa untuk meningkatkan kinerja para auditor BPK Perwakilan Provinsi Jawa Tengah dapat dilakukan melalui upaya-upaya untuk meningkatkan loyalitas, pemenuhan penghasilan yang sesuai, kegiatan kebersamaan (gathering), dan pola penempatan/mutasi sesuai dengan domisili pegawai.

\section{Pengaruh Time Pressure terhadap Kinerja}

Hasil pengujian hipotesis menunjukkan bahwa time pressure dalam setiap pelaksanaan tugas di BPK Perwakilan Provinsi Jawa Tengah berpengaruh terhadap 
kinerja. Hasil penelitian ini sejalan dengan penelitian yang dilakukan Dewi (2011), Orfus (2008), dan Moore dan Tenney (2012) yang menyimpulkan bahwa time pressure berpengaruh terhadap kinerja.

Hal tersebut dapat diartikan bahwa pimpinan BPK Perwakilan Provinsi Jawa Tengah dapat meningkatkan kinerja auditor BPK melalui pengelolaan time pressure yang tepat. Dengan pengelolaan time pressure yang tepat maka dapat meningkatkan kinerja auditor BPK Perwakilan Provinsi Jawa Tengah.

\section{PENUTUP}

Pokok permasalahan dalam penelitian ini adalah belum optimalnya kinerja auditor, berdasarkan hasil penelitian dan pembahasan pada bagian sebelumnya, dapat disimpulkan bahwa peningkatan kinerja dapat dilakukan melalui peningkatan affective commitment melalui upaya-upaya dalam bentuk kegiatan yang terkait dengan peningkatan loyalitas, pemenuhan penghasilan yang sesuai, kegiatan kebersamaan (gathering), dan pola penempatan/mutasi sesuai dengan domisili pegawai.Penelitian ini juga menyimpulkan bahwa pengelolaan time pressure yang tepat dengan berorientasi pada pengelolaan dan alokasi waktu yang tepat dalam setiap penugasan efektif untuk dapat meningkatkan komitmen dan kinerja.

Berdasarkan hasil analisis data dan pembahasan, penelitian ini sebagai berikut;Teamwork berpengaruh terhadap affective commitment sejalan dengan penelitian yang dilakukan oleh Greenberg, et al. (2010) dan Purba (2015); Time pressure berpengaruh terhadap affective commitment sejalan dengan penelitian yang dilakukan oleh Suprapta (2016), Iswari (2015), dan Maya (2011); Teamwork tidak berpengaruh terhadap kinerja sejalan dengan penelitian yang dilakukan oleh Rakhmawati dan Darmanto (2014); Affective commitment berpengaruh terhadap kinerja sejalan dengan penelitian yang dilakukan oleh Suswati dan Budianto (2013), Nurbiyati dan Wibisono (2014), Nurandini dan Lataruva (2014), Tree dan Suryoko (2016) dan Pathan, Natsir dan Adda (2017); dan Time pressure berpengaruh terhadap kinerja sejalan dengan penelitian yang dilakukan oleh Dewi (2011), Orfus (2008), dan Moore dan Tenney (2012).

Implikasi kebijakan yang dapat dilakukan dengan mengacu pada hasil penelitian ini antara lain; perlunya membangunatau meningkatkan rasa memiliki terhadap BPK Perwakilan Provinsi Jawa Tengah dengan saling memberikan motivasi baik didalam tim maupun di lingkungan BPK Perwakilan Provinsi Jawa Tengah; Meningkatkan komitmen afektif para auditor melalui pengelolaan time pressure yang tepat dengan berorientasi pada pengelolaan dan alokasi waktu yang tepat dalam setiap penugasan; Peningkatan kinerja para auditor BPK Perwakilan Provinsi Jawa Tengah melalui upayaupaya dalam meningkatkan loyalitas, pemenuhan penghasilan yang sesuai, kegiatan kebersamaan (gathering), dan pola penempatan/mutasi sesuai dengan domisili pegawai; Meningkatkan kinerja para auditor BPK Perwakilan Provinsi Jawa Tengah melalui pengelolaan time pressure yang tepat dengan berorientasi pada pengelolaan dan alokasi waktu yang tepat dalam setiap penugasan.

Adapun keterbatasan yang ditemukan dalam penelitian ini adalah berdasarkan nilai path coefficient atas pengaruh teamwork terhadap kinerja adalah sebesar 1,689 menunjukkan bahwa teamwork merupakan variabel dalam penelitian ini yang memberikan pengaruh terkecil terhadap kinerja. Berdasarkan keterbatasan dalam 
penelitian ini, maka untuk agenda penelitian mendatang dapat dikembangkan hal-hal sebagai berikut;Melakukan penelitian kualitatif dan kuantitatif (mixed method) untuk menghasilkan fakta yang lebih komprehensif dalam meneliti masalah penelitian; Menambahkan variabel atau faktor lain yang berpengaruh terhadap kinerja antara lain integritas, independensi atau profesionalisme.

\section{DAFTAR PUSTAKA}

Adityasetyaman, 2011. Variabel Penelitian dan Definisi Operasional, Jakarta: Salemba Medika

Boakye, E. O., 2015. The Impact of Teamwork on Employee Performance https://www.researchgate.net/publication/284732729 The impact of teamwork on employee performance

Ghozali, Imam. 2016. Aplikasi Analisis Multivariate Dengan Program SPSS, Semarang: Badan Penerbit Universitas Diponegoro.

Greenberg, E. S., Sikora, P.B., Grunberg, L., \& Moore, S., (2008). Work Teams and Organizational Commitment: Exploring the Influence of the Team Experience on Employee Attitude, Workplace Change Project Working Paper WP-012.

Handoko, T. H. 2012. Manajemen Personalia Dan Sumber Daya Manusia, Edisi Ketiga. Penerbit BPFE. Yogyakarta.

Jogianto, 2010. Analisis Sekuritas dan Analisis Investasi, Yogyakarta : BPFE

Manzoor, S. R., Ullah, H., Hussain, M., Ahmad, Z. M., 2011. Effect of Teamwork on Employee Performance, International Journal of Learning \& Development, ISSN 2164-4063, Vol. 1, No. 1.

Mardalis, 2009. Manajemen Sumber Daya Manusia, Edisi Kelima, Yogjakarta : BPFE.

Marpaung, Marudut. 2014. Pengaruh Kepemimpinan dan Team Work Terhadap Kinerja Karyawan di Koperasi Sekjen Kemdikbud Senayan Jakarta, Jurnal Ilmiah WIDYA, Volume 2 Nomor 1.

Meyer. J. and Allen, N. (1997), Commitment in the Workplace: Theory, Research, and Application, Sage Publications.

Moore, D. A., and Tenney, E. R., 2012. Time Pressure, Performance, and Productivity, Research on Managing Groups and Teams, 15, 305-326.

Mulyadi. 2015. Akuntansi Biaya, Edisi 5. Yogyakarta : Sekolah Tinggi Ilmu Manajemen YKPN.

Nurandini, Arina dan Eisha Lataruva, 2014. Analisis Pengaruh Komitmen Organisasi Terhadap Kinerja Karyawan (Studi Pada Pegawai Perum PERUMNAS Jakarta), Jurnal Studi Manajemen \& Organisasi, 11, Juni 78 - 91.

Nurbiyati, Titik dan Kunto Wibisono, 2014. Analisis Pengaruh Komitmen Afektif, Kontinyu dan Normatif Terhadap Kinerja dengan Disiplin Kerja Sebagai Variabel Intervening, Jurnal Kajian Bisnis, Vol. 22, No. 1, 21 - 37.

Pathan, Natsir dan Adda, 2017. Analisis Pengaruh Komitmen Afektif, Komitmen Berkelanjutan dan Komitmen Normatif Terhadap Kinerja Karyawan pada PT. Radio Nebula Nada di Kota Palu, Jurnal Ilmu Manajemen Universitas Tadulako, Vol. 3, No.1, 138-152. 
Prasetyo, Aji, 2016. Effect of Work Characteristic And Job Satisfaction To Commitment Organization Mediated By Work Life Quality (Studi Case On Employees PT. SE Semarang, Journal of Management, Vol.2 No.2

Priyono, 2016. Sumber Daya Manusia, Edisi Ketiga, Surabaya : Andi Offset.

Qashim, M. dan Rasheed, S., 2017. The Effect of Team Work on Employees Job Performance (The Empirical Assessment of Bank Sector, Afghanistan), International Journal for Innovative Researchin Multidisciplinary Field, Vol. 3, Issue-1.

Rakhmawati dan Darmanto, 2014. Pengaruh Gaya Kepemimpinan Transformasional, Kepercayaan, dan Kerjasama Tim Terhadap Komitemen Organisasi Untuk Meningkatkan Kinerja Karyawan, Media Ekonomi dan Manajemen, Vol. 29 No. 1 Januari 2014.

Robbins, Stephen P. dan Timothy A. Judge. 2008. Perilaku Organisasi Edisi ke-12, Jakarta: Salemba Empat.

Rosally, Catherina dan Yulius Jogi, 2015. Pengaruh Konflik Peran, Ketidakjelasan Peran, Dan Komitmen Organisasi Terhadap Kinerja Auditor, Business Accounting Review, Vol.3 No. 2.

Rustiarini, N. W., 2013. Pengaruh Kompleksitas Tugas, TekananWaktu, dan Sifat Kepribadian pada Kinerja, Makara Seri Sosial Humaniora, 17(2): 126-138.

Sarwono, 2015. Metode Penelitian Kuantitatif : Dilengkapi Perhitungan Manual \& SPSS. Edisi Pertama, Cetakan ke 1, Jakarta: Kencana Prenada Media Group.

Siregar, 2013. Metode Penelitian, Bandung : CV. Alpha

Sholihin, Mahfud dan Ratmono, Dwi. 2013. Analisis SEM-PLS dengan PLS 3.0 untuk Hubungan Nonlinear dalam Penelitian Sosial dan Bisnis. Yogyakarta: Penerbit Andi.

Sugiyono, 2012. Metode Penelitian Bisnis, CV. Alfabeta, Bandung Sutrisno Hadi, 2012. Metode Penelitian Pendidikan, CV. Alfabeta, Bandung

Tree, Evan \& Sri Suryoko, 2016. Pengaruh Komitmen Afektif, Komitmen Berkelanjutan, Komitmen Normatif Terhadap Kinerja Karyawan Melalui Variabel Organization Citizenship Behavior (OCB) Sebagai Variabel Intervening pada PT. Temprina Media Grafika Semarang, Jurnal Ilmu Administrasi Bisnis, Vol. 5 No. 3. 